\title{
К ВОПРОСУ О КОНСТИТУЦИОННО-ПРАВОВОЙ ЗАЩИТЕ ПРАВ ДЕТЕЙ В РОССИЙСКОЙ ФЕДЕРАЦИИ
}

\begin{abstract}
Аннотация: В статье анализируется проблема конституционно-правовой защиты прав ребенка в Российской Федерачии. В работе поставлена иель: сформулировать предложения, направленные на совершенствование российского законодательства в данной области, а также проанализировать общепризнанные международные нормы, имплементированные в российское законодательство. Предмет исследования составляют нормы международного права в области защиты прав ребенка, нормы конституционного законодательства, практика применения этих норм. Исследование показало, что процесс развития законодательства о защите прав ребенка подвержен одновременному воздействию нескольких факторов, среди которых: социальноэкономические преобразования, коренная ломка сложивщихся жизненных устоев общества, социальная нестабильность, смена прежних ценностей. Предлагается внести изменения и дополнения в Федеральный конституционный закон "О судебной системе РФ».В статье сделаны выводы о необходимости законодательного урегулирования статуса Уполномоченного по правам ребенка в Российской Федерации и ее субъектах, а также принятия Федерального закона «О ювенальной юстиции в Российской Федерации».

Abstract: The article is aimed at formulating propositions in order to improve the Russian legislation in this sphere, as well as analysis of the generally recognized international norms implemented into the Russian legislation. The object of studies includes norms of international law in the sphere of protection of rights of children, norms of constitutional legislation, and practice of their implementation. The study has shown that the process of development of legislation on the protection of the rights of children is simultaneously influenced by a number of factors, including social and economic changes, the abrupt change in the values of the society, social instability. The authors offer to amend the Federal Constitutional Law "On the Judicial System of the Russian Federation". The author contains conclusions on the need for legislative regulation of the status of the Plenipotentiary on the Rights of Children in the Russian Federation and its constituent subjects and also to adopt a Federal Law "On Juvenile Justice in the Russian Federation".

Ключевые слова: защита прав ребенка, международные нормы, законодательство, государство, юридические гарантии, общество, государственная политика, конституция, уполномоченный по правам, ювенальная юстиция Keywords: protection of the rights of children, international norms, legislation, state, legal guarantees, society, state policy, constitution, plenipotentiary on human rights, juvenile justice.
\end{abstract}

T ема защиты прав ребенка в современной России не теряет своей злободневности и остроты. Сегодня, как представляется, актуальность этой проблемы даже возросла. В последнее время, как в доктринальных, так и в нормативных источниках акцентируют внимание на необходимости дифференцирования прав взрослых граждан и прав детей, называя детей «специальным субъектом права». В марте 2009 г. на совещании, посвященном предотвращению насилия в отношении детей, Д.А. Медведев сказал: «России нужна современная система защиты детства. Сегодня системы просто нет». В Послании Федеральному Собранию Российской Федерации за 2010 год Д.А. Медведев отметил, что «общество, в котором на деле защищены права ребенка, не только добрее, это общество, быстрее и лучше развивается, имеет благоприятную предсказуемую перспективу»1 ${ }^{1}$

Надо сказать, что политика Российской Федерации в области детства базируется на общепризнанных международных нормах, имплементированных в российское законодательство. В Декларации прав ребёнка (утверждена Ассамблеей Организации Объединённых Наций), провозглашено, что человечество обязано дать ребёнку лучшее, что имеет. А Конвенцией $\mathrm{OOH}$ о правах ребёнка установлен приоритет интересов детей перед интересами общества и государства. В связи с этим в 2009 году при Президенте Российской

\footnotetext{
${ }^{1}$ Послание Президента Российской Федерации Д.А. Медведева Федеральному Собранию РФ от 30 ноября 2010 г. // Парламентская газета. 2010. 3 декабря.
} 
DOI: 10.7256/1811-9018.2013.12.9800

При цитировании этой статьи сноска на dоі обязательна

\section{Право и политика $12(167) \cdot 2013$}

Федерации был создан институт Уполномоченного по правам ребёнка ${ }^{2}$ - как инструмент независимого государственного контроля за соблюдением прав и законных интересов детей, как действенный механизм защиты прав как отдельных детей, так и групп детей.

Однако надо отметить, что, несмотря на то, что права ребенка в Российской Федерации закрепляет ряд нормативных правовых актов, и они в целом обеспечены законодательно, проблема состоит в том, что чаще всего эти права носят декларативный характер.

В этой связи заслуживает всесторонней поддержки мнение профессора А. Бастрыкина, согласно которому «нельзя ссылаться на недостаток финансирования и кризис... Нет времени ждать выполнения программ, которые рассчитаны на десятилетия. Решать проблемы защиты детей годами - непозволительная роскошь. Нужно, чтобы уже сейчас каждый ребенок чувствовал заботу и уверенность в завтрашнем дне»³.

Как было сказано выше, права ребенка, как и права взрослого человека, обеспечены соответствующими нормативными правовыми актами, среди которых важнейшими являются Конституция Российской Федерации, Декларация прав ребенка 1959 года и Конвенция ООН о правах ребенка 1989 года. Положения международных договоров воплощены и получили свое развитие в национальных правовых актах, в частности: в Федеральном законе «Об основных гарантиях прав ребенка в Российской Федерации», в Гражданском, Семейном, Уголовном кодексах Российской Федерации, в указах Президента России и др.

В Декларации прав ребенка признается, что «ребенку законом и другими средствами должна быть обеспечена специальная защита», и в силу этого дети должны быть объектом особой защиты и помощи. И хотя на конституционном уровне в России не применяется понятие «ребенок», тем не менее, существует ряд норм, относящихся к защите прав категории «дети»: например, в нормах статьи 38 отмечено, что забота о детях и их воспитание являются обязанностью родителей, дети находятся под защитой государства. В статье 7 Российская Федерация объявлена социальным государством, сказано, что государственную политику необходимо направить на то, чтобы создать условия, которые обеспечат человеку достойную жизнь и свободное развитие. Российская

\footnotetext{
${ }^{2}$ Об Уполномоченном при Президенте Российской Федерации по правам ребенка: указ Президента РФ от 1 сентября 2009 г. № 986 // Российская газета. Федеральный выпуск № 990 от 4 сентября 2009 г.

${ }^{3}$ См.: Бастрыкин А. На защите прав несовершеннолетних // Законность. 2009. № 9.
}

Конституция закрепляет обеспечение государственной политики поддержки семьи, материнства, отцовства и детства. И, конечно же, в статье второй федеральной Конституции права и свободы человека провозглашаются высшей ценностью, а их соблюдение и защита признаются обязанностью государства.

За последние годы принято большое количество нормативных правовых актов в сфере защиты прав и интересов детей, в том числе законы, указы Президента России и постановления Правительства России. Проведенный мониторинг законодательства и правоприменительной практики субъектов Федерации показал, что аналогичные статьи существуют и в конституциях (уставах) всех субъектов РФ, а также в региональном законодательстве ${ }^{4}$.

Значительно активизировалась деятельность структур, которые занимаются проблемами семьи и детства в органах государственной власти на федеральном уровне, а также в субъектах Федерации. Большим стимулом к реализации новых подходов к решению разных проблем жизнедеятельности детей являются целевые программы федерального, регионального и местного значения 5 .

Особую роль в системе гарантий прав и свобод играют юридические гарантии, через которые обеспечиваются разные стадии процесса реализации, охраны и защиты прав и свобод ребенка. Юридические

\footnotetext{
${ }^{4}$ Обеспечение единого правового пространства Российской Федерации: мониторинг регионального законодательства: Отчет о деятельности Центра регионального законодательства при ФГБОУ ВПО «Дагестанский государственный университет» / Сост. Д.Ш. Пирбудагова, Ш.Б. Магомедов и др. Махачкала, 2011.

${ }^{5} \mathrm{O}$ защите детей от информации, причиняющей вред их здоровью и развитию: Федеральный закон от 29.12.2010 № 436-ФЗ (ред. от 02.07.2013) // Российская газета 2011; Об основных гарантиях прав ребенка в Российской Федерации: Федеральный закон от 24.07.1998 № 124-Ф3 (ред. от 02.07.2013) // Рос. газ. 5 августа. 1998. № 147; Об основах системы профилактики безнадзорности и правонарушений несовершеннолетних: Федеральный закон от 24.06.1999 № 120-Ф3 (ред. от 02.07.2013) // Российская газета. № 121. 30.06.1999; О создании Фонда поддержки детей, находящихся в трудной жизненной ситуации: Федеральные целевые программы защиты прав ребенка и поддержки детства: указ Президента РФ от 26 марта 2008 г. № 404 (ред. от 29.12.2012) // Рос. газ. 29 марта. 2008. № 68; О защите прав ребенка в Республике Дагестан: закон Республики Дагестан от 15 декабря 1998 г. № 24 (ред. от 17.06.2013) // Собрание законодательства Республики Дагестан. 31.12.1998. № 12, ст. 2550; Об уполномоченном Президента Республики Дагестан по правам ребенка: указ Президента Республики Дагестан от 17 апреля 2006 г. № 35. (ред. от 18.02.2013) //Доступ из справ.-правовой системы «Консультант регион»; Концепция федеральной целевой программы «Дети России» на 2007-2010 годы, включающая подпрограммы «Здоровое поколение», «Одаренные дети» и «Дети и семья»; распоряжение Правительства Российской Федерации от 26 января 2007 г. № 79-р г. Москва // Рос. газ. 2007. 2 февраля.
} 
гарантии прав и свобод подразделяют на внутригосударственные и международные механизмы гарантий прав человека и гражданина.

Защита и непосредственное обеспечение прав и свобод человека и гражданина должны осуществляться, прежде всего, на уровне национального законодательства. Степень гарантированности прав и свобод ребенка в каждом конкретном государстве определяет не столько перечень прав и свобод, закрепленных в его законодательстве, сколько уровень развития механизмов и разработанности процедур, используемых при защите данных прав. Несмотря на различия в форме и содержании этих институтов, существуют внутригосударственные институты, их главной задачей является гарантирование защиты прав ребенка. К ним относятся: Президент Российской Федерации - как гарант прав и свобод граждан, судебная власть (суды общей юрисдикции, конституционные и уставные суды субъектов РФ, Конституционный Суд Российской Федерации), Общественная палата РФ (общественные палаты субъектов РФ), Уполномоченный по правам человека (уполномоченные по правам человека субъектов РФ), Уполномоченный по правам ребенка при Президенте РФ (уполномоченные по правам ребенка субъектов РФ), независимые СМИ и др.

В последние годы на федеральном уровне сформировался новый для России самостоятельный государственно-правовой институт Уполномоченного по правам ребенка ${ }^{6}$, независимый от ведомственных интересов, получивший высокую оценку международного сообщества и высших органов государственной власти Российской Федерации.

Однако в современных российских реалиях состояние дел в области защиты прав ребенка пока оставляет желать лучшего, поэтому необходимость усиления законодательного регулирования в этой области вполне очевидна. Ведь от того, насколько эффективно в государстве защищены права детей, зависит будущее государства.

Итак, можно сделать вывод о том, что проблема соблюдения, охраны и защиты прав детей сегодня является чрезвычайно актуальной для России. Надо также подчеркнуть, что социально-экономические преобразования, коренная ломка сложившихся жизненных устоев общества, отрицательно сказавшиеся на населении, способствовали падению уровня жизни множества

\footnotetext{
${ }^{6}$ В Указе Президента РФ было рекомендовано органам государственной власти субъектов Российской Федерации учредить должность уполномоченного по правам ребенка. В настоящее время в каждом субъекте РФ существует институт Уполномоченного по правам ребенка.
}

российских граждан, социальной нестабильности, ломке прежних ценностей, от чего больше всего страдают дети․ «Мы столкнулись с чудовищным парадоксом: детей приходится защищать от их же защитников» ${ }^{8}$.

Тогда как надо обратить внимание на то, что в настоящее время во всем мире показателем демократичности государства считается обеспечение прав гражданина в любом возрасте, включая детей. По этой причине одной из главнейших задач нашего государства служит совершенствование данного направления деятельности.

Очень важна социальная адаптация детей, находящихся в трудной жизненной ситуации. В этой связи в качестве превентивной меры, как нам кажется, необходимо выявлять и устранять причины и условия, способствующие нарушению прав детей в Российской Федерации.

Представляется важным законодательное урегулирование статуса Уполномоченного по правам ребенка в Российской Федерации и ее субъектах. Необходимо принять Федеральный закон «О ювенальной юстиции в Российской Федерации»", который обеспечит действенную государственную защиту прав и охраняемых законом интересов детей, а также внести изменения и дополнения в Федеральный конституционный закон от 31 декабря 1996 г. № 1-ФКЗ «О судебной системе РФ».

\section{Библиография:}

1. Абрамов В.И. Права ребенка и их защита в России: общетеоретический анализ [Электронный ресурс]: автореф. дис. д-ра юрид. наук. Саратов, 2007. С. 5.

2. Бастрыкин А. На защите прав несовершеннолетних // Законность. 2009. № 9.

\section{References (transliteration):}

1. Abramov V.I. Prava rebenka i ikh zashchita v Rossii: obshcheteoreticheskii analiz [Elektronnyi resurs]: avtoref. dis. d-ra yurid. nauk. Saratov, 2007. S. 5.

2. Bastrykin A. Na zashchite prav nesovershennoletnikh // Zakonnost'. 2009. № 9.

\footnotetext{
${ }^{7}$ Послание Президента Российской Федерации Федеральному Собранию. М., 2003. С. 16.

${ }^{8}$ Цит. по: Абрамов В.И. Права ребенка и их защита в России: общетеоретический анализ [Электронный ресурс]: автореф. дис. д-ра юрид. наук. Саратов, 2007. С. 5.

9 Проект закона находится на рассмотрении в Государственной Думе Федерального Собрания Российской Федерации.
} 